\title{
EduRom: Promoting the access of Roma to LLP, VET and employment through family education in Primary schools
}

\author{
Lifelong Learning Programme. European Comission
}

(2013-2015)

\section{Research summary}

Over the last two decades, it is apparent that the socio-economic situation of many Roma people has stagnated or even deteriorated in a number of EU Member States. Many Roma people experience unemployment, low income, reduced life expectancy and poor quality of life (Background document of the Final conference on the Adult Learning Action plan - 2011)

According to the EU Framework for National Roma Integration Strategies up to 2020, in some Member States, only a limited number of Roma children complete primary school. Roma children tend to be over-represented in special education and segregated schools. As a result of this situation there are a high number of Roma adult people without basic qualifications.

The low skilled are the most at risk of unemployment, as evidenced since the crisis. Raising their skills levels is of paramount importance as their next employment often means a move from manual work to the service sector, which may demand higher literacy and digital skills. Cedefop research shows that in 1996 31\% of the workforce required only low skills but by 2020 this figure will fall to $18 \%$. This should be a major stimulus to act, reinforced by the fact that the low skilled are the most vulnerable to unemployment (Action Plan on Adult Learning: Achievement and results 2008-2011. Comission staff working paper)

At the same time, empirical evidence and research on the socio-economic situation of Roma show that there is a significant gap between the employment rate for Roma and the rest of the population. The World Bank found that Roma employment rates (especially for women) fall well behind those of the non-Roma majority (EU Framework for National Roma Integration Strategies up to 2020). 
The EduRom poject is based mainly on the European strategy, the Action Plan on Adult Learning and contributions from previous research studies, such as Include-ed, Brudila callí, Roma-in and Workaló.

Includ-ed project has identified successful educational actions which, based on scientific evidences, contributes to overcome social exclusion and to achieve educative success of Roma from the most disadvantaged areas. Brudilla Callí underlines the importance of the participation of Roma parents in the school community. ROMAin proposes learning communities and transformation of learning at school to facilitate inclusion of Roma population. Adding to that, Workaló states that the Roma population has developed specific abilities and competences related to the type of work they have been doing, such as team players, flexibility and capacity to adapt in a changing environment, negotiation skills, however, most of Roma people do not have academic degrees and formal work experiences. Thus, Roma people are qualified but they lack of formal credentials of their competences.

Therefore, taking into account contributions from previous researches, and the main policies and EU recommendations, the EduRom motivations are:

- $\quad$ to improve Roma key competence skills through family education courses in primary schools and to encourage the non-formal and informal learning validation of Roma to facilitate their access to LLP, VET and employment.

- to work against school failure and early school leavers in Roma community, bringing primary schools and Roma families closer to each other, promoting the participation in school of families and all the community.

Through the project we will achieve enabling validation of non-formal and informal learning processes for early school-leavers and low-skilled adults that is one of the challenges for future policies at EU, national and regional levels (Background document of the Final conference on the Adult Learning Action Plan (2011):"One Step Up" Enhancing Adult Competences); and responds to the Action Plan on Adult learning of the EC (2007), assessment and recognition of skills and social competences, regardless of where and how they are achieved, are especially important for those who do not have basic qualifications, in order to facilitate their integration in society.

On the other hand, there is a need to strengthen links with communities through cultural/school mediators, churches, religious associations or communities and through active participation of the parents of Roma, to improve the intercultural competences of teachers, to reduce segregation and to ensure compliance with the duty to primary school attendance. (EU Framework for National Roma Integration Strategies up to 2020)

In this way, the Edurom project addresses some significant measures that contribute to the development of a robust provision of basic skills for low-skilled individuals defined in the Comission staff working paper. Action Plan on Adult Learning: 
Achievement and results 2008-2011 and specifically: outreaching to the learner in his/her local environment or workplace; taking into consideration labour market needs and how employers, the workplace and the community can enable low-skilled individuals to take their qualifications "one step up", including embedding basic skills in vocational education and training or work; establishing collaborative arrangements between key stakeholders at national, regional and local levels for the development of policies and the provision of resources for basic skills and established or emerging guidance services (and validation) to support and motivate adults seeking to develop or improve their basic skills.

EduRom wants to apply at local level in several European countries, recommendations done previously by international scientific community to raise participation and attainment levels of Roma students in general education and VET and concretely the following:

- The participation of families in family education programmes in schools is a successful action that raises students' achievement. Family and community members should participate in the decisions about these family education programmes in schools.

- Participation of families from vulnerable groups (migrants, cultural minorities and of students with disabilities) should be particularly encouraged as it related to their children's academic success.

\section{Research Team Members:}

Main researcher: Carme Garcia Yeste (Universitat Rovira i Virgili)

Aitor Gómez González (Universitat Rovira i Virgili)

\section{Partners}

Romani Association of Women Drom Kotar Mestipen (Spain)

Amalipe Center for Interethnic Dialogue and Tolerance (Bulgaria)

Roma Women Association of Drosero "Elpida" (Greece)

Pavee Point Travellers' Centre (Ireland)

NGO Slovo 21 (Czech Republic)

Roma Woman Association "For Our Children" (Romania)

Federació d'Associacions Culturals i Educatives de Persones Adultes (Spain)

Direcció General d'Acció Cívica i Comunitària. Generalitat de Catalunya 